\title{
Muscle biopsy with dystrophic pattern and rimmed vacuoles: GNE myopathy in a Brazilian patient
}

Biópsia de músculo mostrando padrão distrófico e vacúolos marginados: um caso de miopatia GNE em uma paciente brasileira

Eduardo de Paula Estephan', Cristiane Araújo Martins Moreno', André Macedo Serafim da Silva', Rodrigo de Holanda Mendonça ${ }^{1}$, Osório Abath Neto', Patrícia Yoshi Nishimura², Layla Testa Galindo², Edmar Zanoteli

GNE myopathy (MIM\#605820) is a rare autosomal recessive disorder with a higher prevalence in individuals with Middle Eastern or Japanese ancestries ${ }^{1}$. We present a 23-year-old Brazilian female, without such ancestries, with slowly progressive distal and proximal weakness in her lower limbs since the age of 18 . Within five years, weakness progressed to her upper limbs and led to loss of ambulation (sparing the quadriceps somewhat). The muscle biopsy is shown in the Figure. Exome analysis revealed compound heterozygous variants on GNE gene (p.Arg193Cys, known², and p.Arg132Cys, novel). This is the first South American patient report, which illustrates the utility of high-throughput sequencing to diagnose rare and potentially treatable disorders ${ }^{1,3}$.
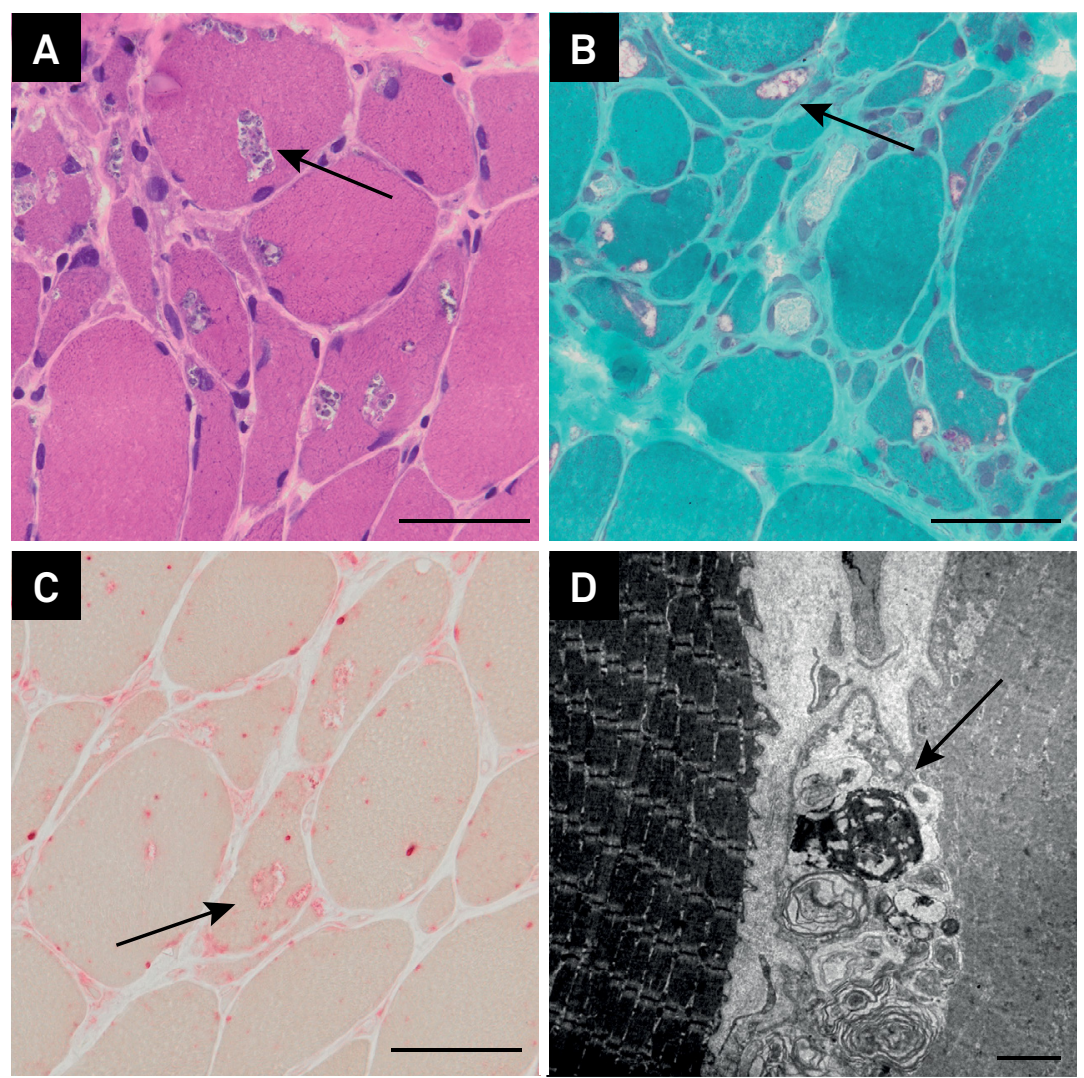

Figure. Dystrophic pattern with rimmed vacuoles with autophagic aspect (arrows) on muscle biopsy. A) H\&E (bar= 50 Hm). B) Gomori's trichrome (bar $=50 \mu \mathrm{m})$. C) Acid phosphatase (bar= $50 \mu \mathrm{m})$. D) Electron microscopy $($ bar $=1000 \mathrm{~nm})$.

'Universidade de São Paulo, Faculdade de Medicina, Departamento de Neurologia, São Paulo SP, Brasil;

${ }^{2}$ Laboratório DASA, Diagnóstico Molecular, São Paulo SP, Brasil.

Correspondence: Edmar Zanoteli; Av. Dr. Enéas de Carvalho Aguiar, 255 / $5^{\circ}$ andar / sala 5084; 05403-900 São Paulo SP, Brasil; E-mail:zanoteli@terra.com.br Conflict of interest: There is no conflict of interest to declare.

Received 22 July 2016; Accepted 01 September 2016. 


\section{References}

1. Nishino I, Carrillo-Carrasco N, Argov Z. GNE myopathy: current update and future therapy. J Neurol Neurosurg Psychiatry. 2015;86(4):385-92. doi:10.1136/jnnp-2013-307051

2. Del Bo R, Baron P, Prelle A, Serafini M, Moggio M, Fonzo AD et al. Novel missense mutation and large deletion of GNE gene in autosomal-recessive inclusion-body myopathy. Muscle Nerve. 2003;28(1):113-7. doi:10.1002/mus.10391

3. Mori-Yoshimura M, Nishino I. [Sialic acid replacement therapy for distal myopathy with rimmed vacuoles]. Brain Nerve. 2015;67(9):1115-23. Japanese. doi:10.11477/mf.1416200269 